\title{
INFLUENCE OF EARTH COMPOSITION ON ADSORPTION CAPACITY OF METHYLENE BLUE DYE
}

\author{
Tereza Plaček Otcovská*, Barbora Mužíková, Pavel Padevět
}

\author{
Czech Technical University in Prague, Faculty of Civil Engineering, Department of Mechanics, Thákurova 7, \\ 16629 Prague 6, Czech Republic \\ * corresponding author: tereza.otcovska@fsv.cvut.cz
}

\begin{abstract}
Final properties of unfired earth are influenced by composition of earth mixtures. Methylene blue test could be useful method for analysis of earth composition. This would facilitate of designing unfired earth building structures because composition of natural earth is various. Principle of methylene blue test is measure of amount of adsorbed methylene blue dye by clay. The essential component of earth mixtures is clay because clay fulfils a function of binder. Experimental measure of adsorption capacity of individual kind of clay is described in this paper. Adsorption capacity was investigated in montmorillonite, kaolinite, illite-kaolinite and illite clays. The obtained results show that the adsorption capacity of clays is significantly different.
\end{abstract}

KEYworDs: Adsorption capacity, clay, methylene blue dye, methylene blue test.

\section{INTRODUCTION}

Unfired earth is a building material which had become minor in 2 nd half of 20th century because of modern building materials such as steel or concrete have have become readily available. Nowadays, the unfired earth is getting back to forefront of interest for its properties that fit into principles of a sustainable building and improving microclimate in interiors [14]. Earth mixture is a basic material for production of unfired earth constructions. Uncertain composition of natural earth is the main reason why using of unfired earth in construction is complicated. It is because of final properties of unfired earth constructions are greatly influenced by the earth composition $[4,5]$. Methylene blue test is described in standard ČSN EN 933-9. Methylene blue test could be a good method for analysis of the earth composition. Basic idea of this research is that every kind of clay (main component of earth mixture) has different adsorption capacity of methylene blue dye. If adsorption capacity of individual clay is known, this test could be a good method for analysing earth composition [5-8].

This paper is focused on experimental determination of adsorption capacity of clay by methylene blue test. Four kinds of clay were investigated (montmorillonite, kaolinite, illite-kaolinite, illite). Minimum number of measurements for each investigated material was 3. The result of this research is the determination of the adsorption capacity of mentioned clay and determination of dependence between the amount of adsorbed dye and amount of clay in earth.

\section{Description of Experimental MeAsuREMENT}

A burette, a beaker, a filter paper, a magnetic stirrer and a glass rod are basic equipment for methylene blue test. Solution of methylene blue dye (methylthioninium chloride - C16H18ClN3S) by concentration $10 \mathrm{~g} / \mathrm{l}$ is used. Earth samples are produced from earth and distilled water. Methylene blue solution is inserted into earth sample by a burette (Fig. 1).

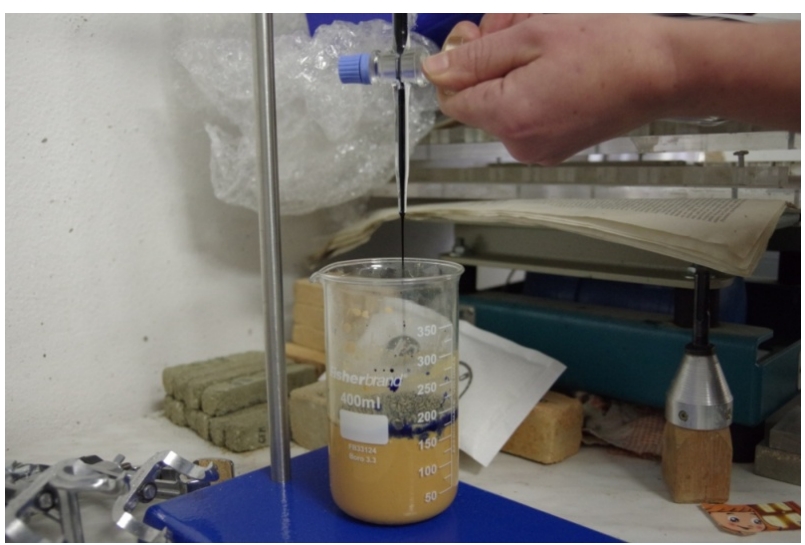

Figure 1. An earth sample with methylene blue solution.

Earth sample with the solution is stirred on a magnetic stirrer 1 minute for each 1 millilitre of solution. After that a drop of the mixture is placed on a filter paper. This process is repeated and each sample drop with increasing amount of methylene blue solution is marked (Fig. 2). Methylene blue test is finished when a blue ring spreads around a drop sample (Fig. 3) because clay has already adsorbed the maximum amount of methylene blue dye.

Amount of dye adsorbed depends on a kind and amount of clay. Amount of dye adsorbed is determined by the Eq. 1. Amount of dye adsorbed is defined as the weight amount of dye in grams that is adsorbed by 1 kilogram of test material. 


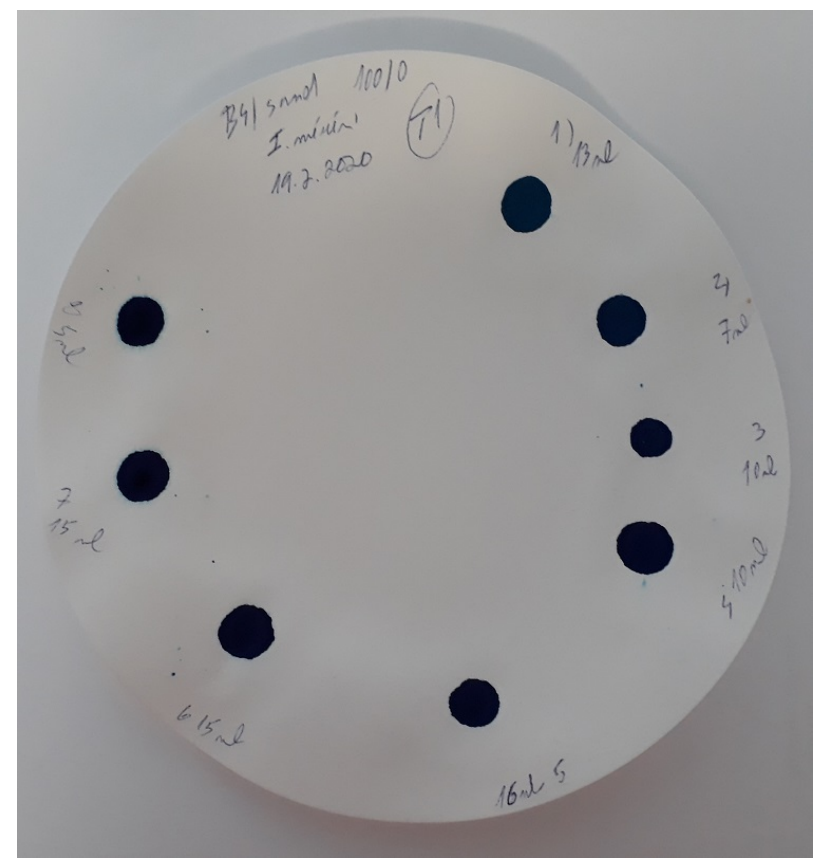

Figure 2. A drop of the mixture is placed on a filter paper.

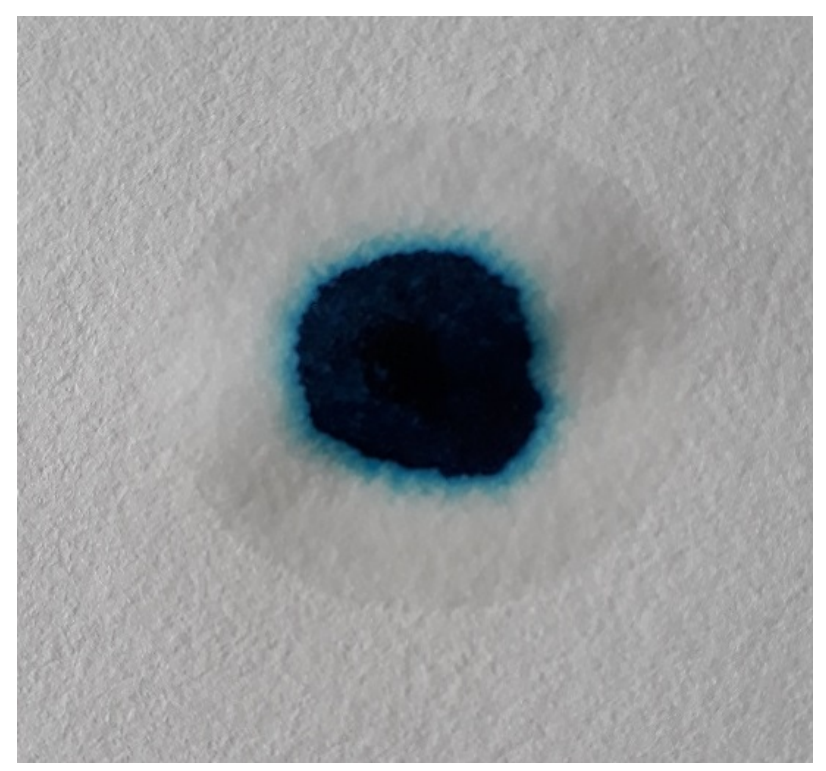

FigURE 3. A result of methylene blue test.

$$
M_{M B}=\frac{m_{s} \cdot m_{M B, 1 m l} \cdot 1000}{M_{E S}}
$$

\section{Investigated Material}

Earth samples are produced in laboratory from sand, clay powder (Fig. 5) and distilled water. A grain curve of sand is shown in Fig. 4. 4 kinds of clay are tested (montmorillonite, kaolinite, illite-kaolinite, illite). Industrial marking which is used in this paper too and chemical composition are shown in Table 1.

Earth samples are suspension of clay and sand in distilled water. Clay and sand are mixed in prescribed ratio (Table 2) and it is solid part of earth

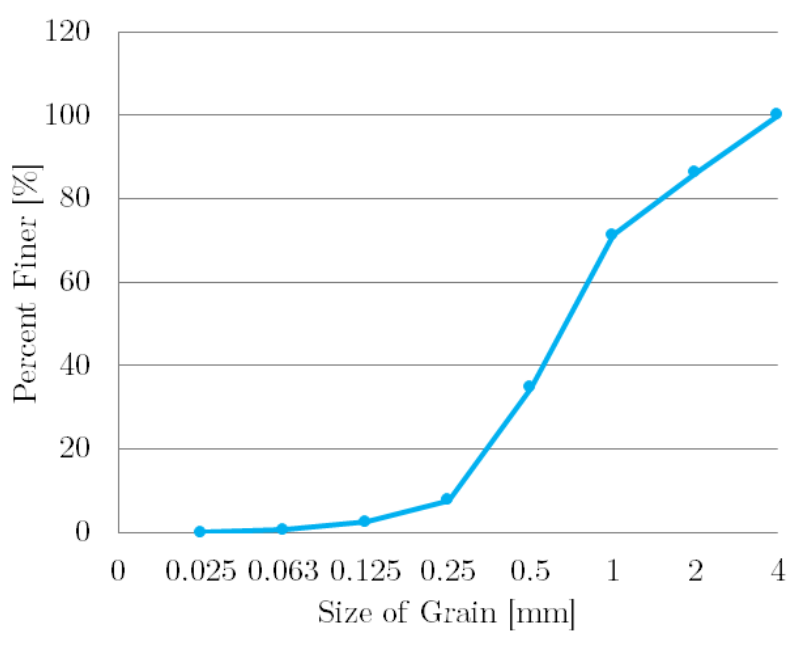

Figure 4. Grain curve of sand.

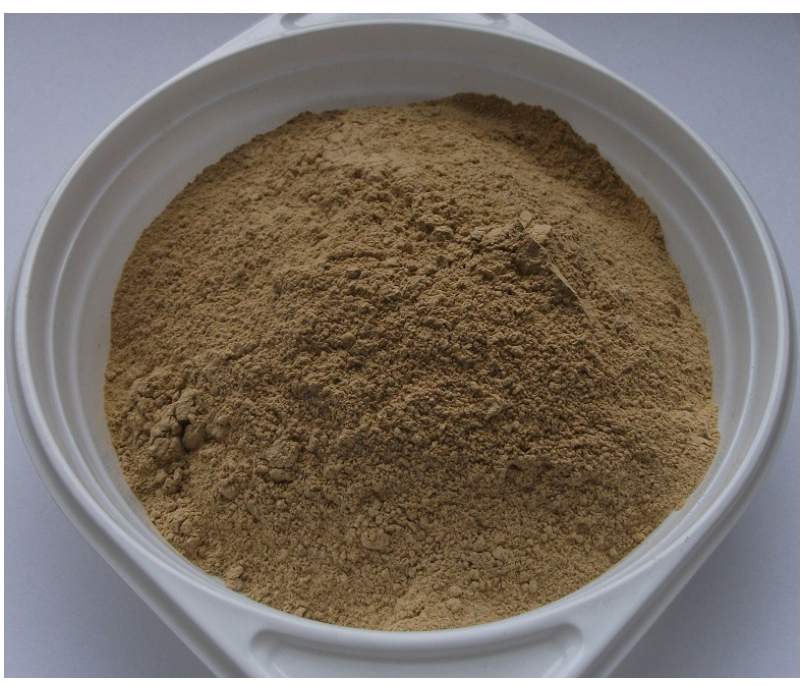

Figure 5. Clay powder.

samples. This solid part is always $15 \mathrm{~g}$. Distilled water is always $75 \mathrm{~g}$. Distilled water serves as a medium for adsorption.

4 clay/sand ratios are used for each kind of clay. 54 measurements are performed on 16 types of samples. The minimum number of measurements for each sample type was 3 . Table 2 shows composition of samples, amount of components and a number of measurements.

Mark of a sample contains mark of clay and percentage number of clay in a sample. Table 2 shows mark of samples.

\section{Adsorption Capacity of Clay}

Adsorption capacity is very different for each kind of clay. The highest adsorption capacity is found for montmorillonite clay (GEM), lower for kaolinite clay (B4), even lower for illite-kaolinite clay (KR) and the lowest for illite clay (AGL). Table 3 and Figure 6 shown results from methylene blue test.

Maximum average amount of adsorbed dye $88 \mathrm{~g} / \mathrm{kg}$ $(\sigma=3.8 \mathrm{~g} / \mathrm{kg})$ is calculated for GEM-100. The clay 


\begin{tabular}{lllllllllll}
\hline $\begin{array}{l}\text { Kind of } \\
\text { clay }\end{array}$ & $\begin{array}{l}\text { Mark of } \\
\text { clay }\end{array}$ & $\begin{array}{l}\mathrm{AMM} \\
{[\mathrm{ml} / \mathrm{g}]}\end{array}$ & $\begin{array}{l}\mathrm{SIO}_{2} \\
{[\%]}\end{array}$ & $\begin{array}{l}\mathrm{AL}_{2} \mathrm{O}_{3} \\
{[\%]}\end{array}$ & $\begin{array}{l}\mathrm{FE}_{2} \mathrm{O}_{3} \\
{[\%]}\end{array}$ & $\begin{array}{l}\mathrm{TIO}_{2} \\
{[\%]}\end{array}$ & $\begin{array}{l}\mathrm{CAO} \\
{[\%]}\end{array}$ & $\begin{array}{l}\mathrm{MGO} \\
{[\%]}\end{array}$ & $\begin{array}{l}\mathrm{NA}_{2} \mathrm{O} \\
{[\%]}\end{array}$ & $\begin{array}{l}\mathrm{K}_{2} \mathrm{O} \\
{[\%]}\end{array}$ \\
\hline Montmorillonite & GEM & 17 & 50.51 & 31.2 & 3.37 & 0.86 & 0.4 & 0.42 & 0.08 & 1.62 \\
Kaolinite & $\mathrm{B} 4$ & 4.5 & 58.13 & 24.29 & 4.7 & 1.21 & 0.13 & 0.5 & 0.5 & 3.96 \\
Illite-kaolinite & $\mathrm{KR}$ & 8.4 & 59.31 & 24.71 & 3.37 & 1.09 & 0.19 & 0.4 & 0.3 & 2.82 \\
Illite & AGL & 29.4 & 56.57 & 18.4 & 9.72 & 1.16 & 1.12 & 2.54 & 0.18 & 2.91 \\
\hline
\end{tabular}

TABLE 1. Chemical composition of used clays.

\begin{tabular}{lllllll}
\hline Clay & $\begin{array}{l}\text { Mark } \\
\text { of sample }\end{array}$ & $\begin{array}{l}\text { Clay/sand } \\
\text { ratio } \\
{[-]}\end{array}$ & $\begin{array}{l}\text { Amount of } \\
\text { distilled water } \\
{[\mathrm{g}]}\end{array}$ & $\begin{array}{l}\text { Amount } \\
\text { of clay } \\
{[\mathrm{g}]}\end{array}$ & $\begin{array}{l}\text { Amount } \\
\text { of sand } \\
{[\mathrm{g}]}\end{array}$ & $\begin{array}{l}\text { Number of } \\
\text { measurements } \\
{[-]}\end{array}$ \\
\hline Montmorillonite & GEM-100 & $100 / 0$ & 75 & 15 & 0 & 3 \\
& GEM-75 & $75 / 25$ & 75 & 11.25 & 3.75 & 4 \\
& GEM-50 & $50 / 50$ & 75 & 7.5 & 7.5 & 3 \\
Kaolinite & GEM-25 & $25 / 75$ & 75 & 3.75 & 11.25 & 5 \\
& B4-100 & $100 / 0$ & 75 & 15 & 0 & 3 \\
& B4-75 & $75 / 25$ & 75 & 11.25 & 3.75 & 3 \\
& B4-50 & $50 / 50$ & 75 & 7.5 & 7.5 & 3 \\
Illite- & B4-25 & $25 / 75$ & 75 & 3.75 & 11.25 & 3 \\
kaolinite & KR-100 & $100 / 0$ & 75 & 15 & 0 & 3 \\
& KR-75 & $75 / 25$ & 75 & 11.25 & 3.75 & 3 \\
& KR-50 & $50 / 50$ & 75 & 7.5 & 7.5 & 4 \\
& KR-25 & $25 / 75$ & 75 & 3.75 & 11.25 & 5 \\
& AGL-100 & $100 / 0$ & 75 & 15 & 0 & 3 \\
& AGL-75 & $75 / 25$ & 75 & 11.25 & 3.75 & 3 \\
& AGL-50 & $50 / 50$ & 75 & 7.5 & 7.5 & 3 \\
& AGL-25 & $25 / 75$ & 75 & 3.75 & 11.25 & 3 \\
\hline
\end{tabular}

TABLE 2. Clays used for experimental measurements, their designation and composition.

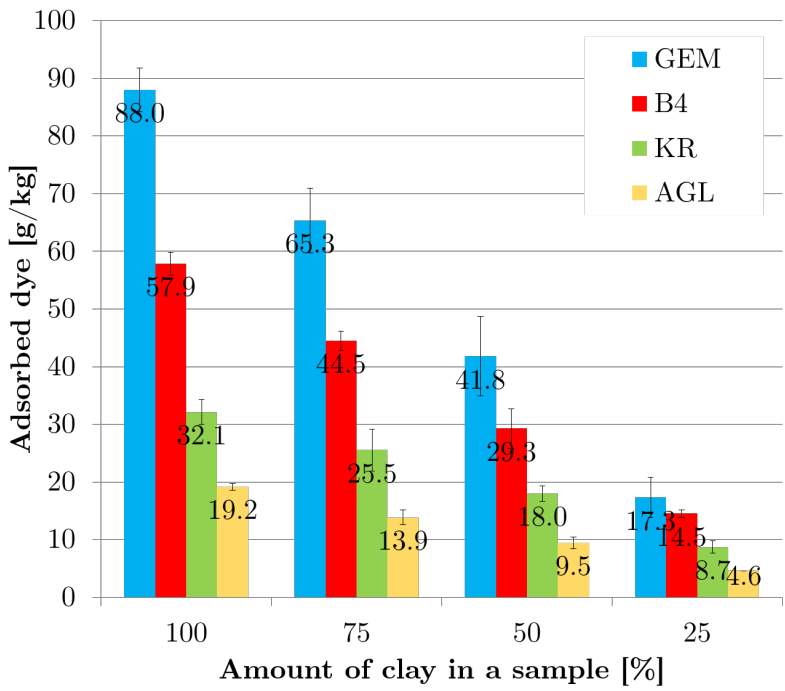

Figure 6. Amount of adsorbed methylene blue dye by clays.

contained in a sample is montmorillonite and clay is $100 \%$ of the solid part of a sample. On the contrary, the lower value of adsorbed dye $4.6 \mathrm{~g} / \mathrm{kg}(\sigma=0 \mathrm{~g} / \mathrm{kg})$ is determined for AGL-25 sample. The clay contained in AGL-25 sample is illite and clay is $25 \%$ of the solid part of a sample.

Compared to montmorillonite clay, the adsorption capacity of kaolinitic clay is $34.3 \%$ lower (e.i. $65.7 \%$ ), illite-kaolinite is $63.5 \%$ lower(e.i. 36.5), illite is $78.2 \%$ lower (e.i. 21.8\%). Figure 6 shows that the same trend was also observed for the samples with a clay content of $75 \%, 50 \%$ and $25 \%$. The percentage difference in adsorption capacity for all clays is given in Table 4 .

Obtained values of adsorbed dye by individual samples are interpolated by a linear regression curve. It can be seen from Figure 7 that dependence of adsorption on amount of clay is linear for all kinds of clays.

\subsection{Confidence Intervals}

From the obtained adsorption values, limits of the confidence interval $L_{1}$ and $L_{2}$ were calculated by Eq. $2(\alpha=0.05)$. Calculated confidence interval limits are given in Table 5 .

$$
L_{1,2}=\bar{x} \pm \frac{\sigma \cdot t_{k}}{\sqrt{n}}
$$

Confidence interval is calculated for all measurement values of adsorption dye. Figure 8 shows dependence between amount of adsorbed dye and amount 


\begin{tabular}{lllll}
\hline Clay & $\begin{array}{l}\text { Mark of } \\
\text { sample }\end{array}$ & $\begin{array}{l}\text { Average amount of } \\
\text { adsorbed dye } \\
{[\mathrm{g} / \mathrm{kg}]}\end{array}$ & $\begin{array}{l}\text { Standard } \\
\text { deviation } \\
{[\mathrm{g} / \mathrm{kg}]}\end{array}$ & $\begin{array}{l}\text { Relative standard } \\
\text { deviation } \\
{[\%]}\end{array}$ \\
\hline Montmorillonite & GEM-100 & 88.0 & 3.8 & 4.3 \\
& GEM-75 & 65.3 & 5.6 & 8.6 \\
& GEM-50 & 41.8 & 6.9 & 16.4 \\
Kaolinite & GEM-25 & 17.3 & 3.5 & 20.1 \\
& B4-100 & 57.9 & 2.0 & 3.5 \\
& B4-75 & 44.5 & 1.7 & 3.7 \\
Illite- & B4-50 & 29.3 & 3.4 & 11.6 \\
kaolinite & B4-25 & 14.5 & 0.7 & 4.5 \\
& KR-100 & 32.1 & 2.1 & 6.6 \\
Illite & KR-75 & 25.5 & 3.6 & 14.2 \\
& KR-50 & 18.0 & 1.4 & 7.6 \\
& KR-25 & 8.7 & 1.1 & 12.4 \\
& AGL-100 & 19.2 & 0.6 & 3.3 \\
& AGL-75 & 13.9 & 1.3 & 9.5 \\
& AGL-50 & 9.5 & 1.0 & 10.7 \\
\hline
\end{tabular}

TABLE 3. Results obtained by methylene blue test.

\begin{tabular}{lllll}
\hline & & \multicolumn{3}{c}{ Amount of adsorbed dye } \\
Amount of clay & $\begin{array}{l}\text { GEM } \\
{[\mathrm{g} / \mathrm{kg}]}\end{array}$ & $\begin{array}{l}\mathrm{B} 4 \\
{[\mathrm{~g} / \mathrm{kg}]}\end{array}$ & $\begin{array}{l}\mathrm{KR} \\
{[\mathrm{g} / \mathrm{kg}]}\end{array}$ & $\begin{array}{l}\text { AGL } \\
{[\mathrm{g} / \mathrm{kg}]} \\
{[\%]}\end{array}$ \\
\hline in a sample & {$[\%]$} & 57.9 & 32.1 & 19.2 \\
\hline \multirow{2}{*}{$15.00 \mathrm{~g} / 100 \%$} & 88.0 & 65.7 & 36.5 & 21.8 \\
& 100 & 44.5 & 25.5 & 13.9 \\
$11.25 \mathrm{~g} / 75 \%$ & 65.3 & 68.1 & 39.1 & 21.2 \\
& 100 & 29.3 & 18.0 & 9.5 \\
$7.50 \mathrm{~g} / 50 \%$ & 41.8 & 70.0 & 43.0 & 22.6 \\
& 100 & 14.5 & 8.7 & 4.6 \\
$3.75 \mathrm{~g} / 25 \%$ & 17.3 & 84.0 & 50.4 & 26.7 \\
\hline
\end{tabular}

TABLE 4. Comparison of the amount of adsorbed dye.

of clay in sample with confidence interval area for each clay.

The curves of adsorption are created by combining the calculated values of adsorption for amount of clay in samples $25 \%, 50 \%, 75 \%$ and $100 \%$. Extreme values of confidence interval area are join between the calculated values of the confidence interval limits L1, $\mathrm{L} 2$.

It can be seen from Figure 8, that illitic clay (AGL) and illitic-kaolinitic clay (KR) can be well distinguished from each other in an amount of clay in solid part at least $25 \%$.

Confidence intervals of montmorillonite (GEM) and kaolinite (B4) clay overlap when clay content is 25-50 \%. Based on Figure 8, it can be assumed that the methylene blue test is applicable for amounts of $75 \%$ and higher in the case of montmorillonite and kaolinitic clays.

\section{Conclusions}

Methylene blue test is applicable to diagnose composition of earth. Each of the investigated clays (montmorillonite, kaolinite, illite-kaolinite, illite) adsorbs a different amount of methylene blue dye. Montmorillonite is characterized by the largest adsorption capacity. The adsorption capacity of methylene blue dye decreases for clays in the order: kaolinite, illitekaolinite and illite (Fig. 6).

Furthermore, it was experimentally determined that the amount of adsorbed dye is directly dependent on the amount of clay in earth (Fig. 7).

Using confidence intervals, it was determined that illitic and illitic-kaolinitic clays can be determined by methylene blue test in earth in quantities from $25 \%$. Montmorillonite and kaolinite clay can be determined by methylene blue test in earth in amounts from $75 \%$ (Fig. 8). 
Amount of Adsorbed Dye Montmorillonite Clay

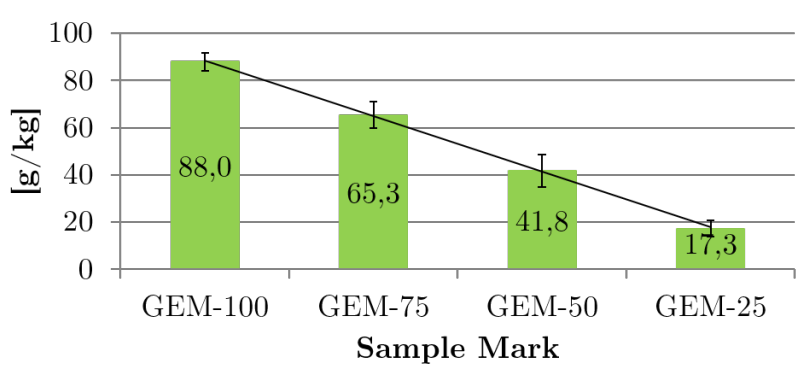

Amount of Adsorbed Dye - Illitekaolinite Clay

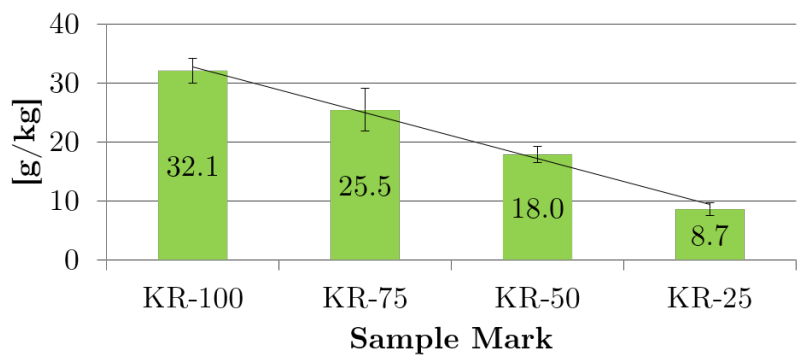

Amount of Adsorbed Dye Kaolinitic Clay

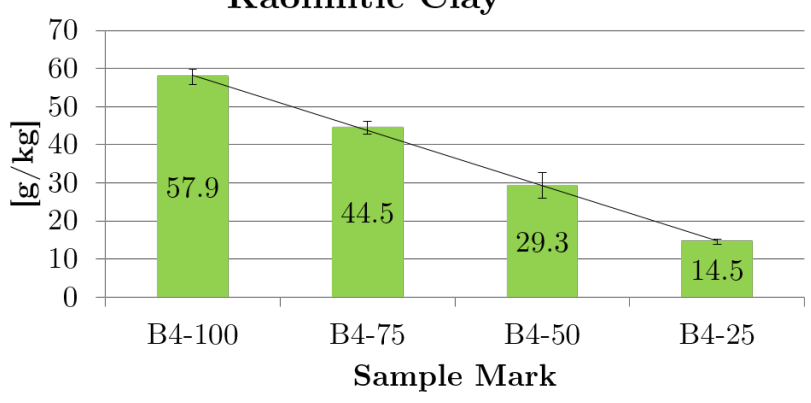

Amount of Adsorbed Dye - Illite Clay

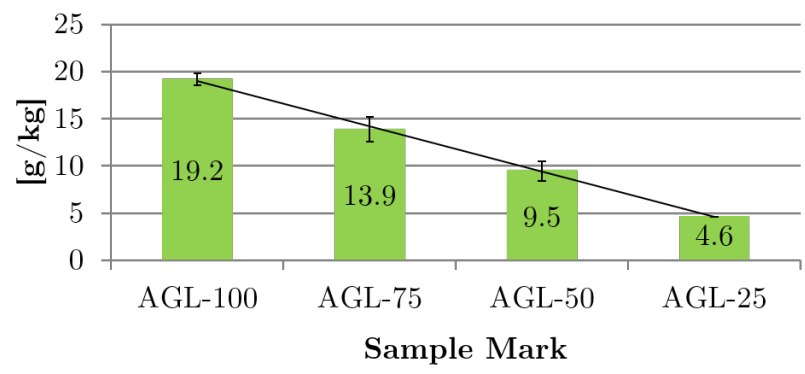

Figure 7. Amount of adsorbed methylene blue dye by clay.

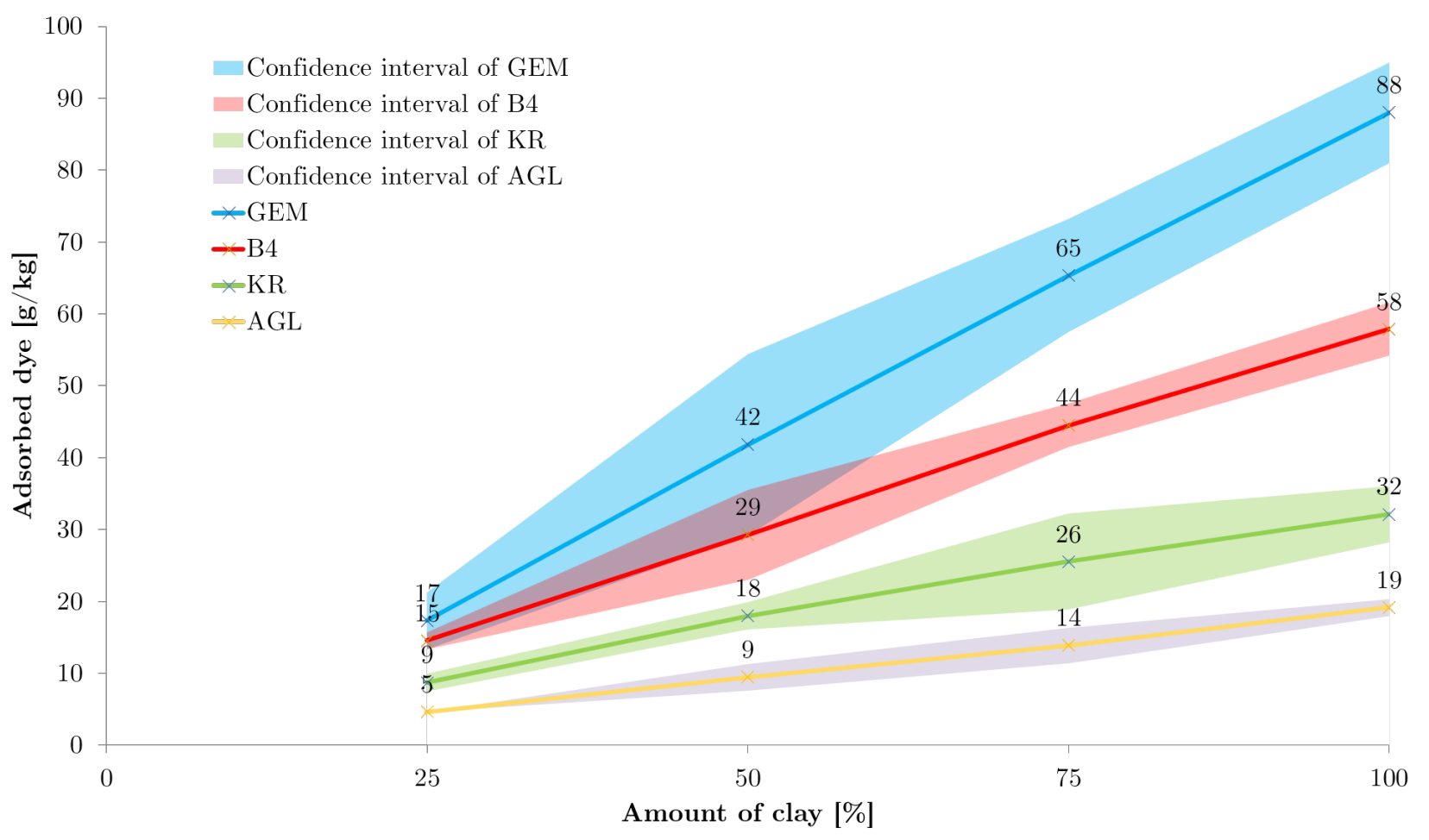

FiguRE 8. Confidence intervals of clays. 


\begin{tabular}{|c|c|c|c|}
\hline Clay & Mark of sample & \multicolumn{2}{|c|}{$\begin{array}{l}\text { Confidence interval } \\
{[\mathrm{g} / \mathrm{kg}]}\end{array}$} \\
\hline \multirow{4}{*}{ 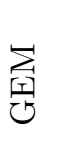 } & GEM-25 & 13.31 & 21.29 \\
\hline & GEM-50 & 29.18 & 54.43 \\
\hline & GEM-75 & 57.54 & 73.16 \\
\hline & GEM-100 & 81.01 & 95.01 \\
\hline \multirow{4}{*}{$\ddot{p}$} & B4-25 & 13.31 & 15.73 \\
\hline & B4-50 & 23.04 & 35.49 \\
\hline & $\mathrm{B} 4-75$ & 41.45 & 47.53 \\
\hline & B4-100 & 54.16 & 61.57 \\
\hline \multirow{3}{*}{$\underline{1}$} & $\mathrm{KR}-25$ & 7.49 & 9.96 \\
\hline & KR-50 & 16.10 & 19.88 \\
\hline & KR-75 & 18.84 & 32.20 \\
\hline \multirow{5}{*}{$\underset{\varangle}{\mho}$} & KR-100 & 28.23 & 36.02 \\
\hline & AGL-25 & 4.62 & 4.62 \\
\hline & AGL-50 & 7.61 & 11.31 \\
\hline & AGL-75 & 11.44 & 16.29 \\
\hline & AGL-100 & 18.01 & 20.32 \\
\hline
\end{tabular}

TABLE 5. Calculated confidence interval limits of adsorption for clays $(\alpha=0.05)$.

\section{LIST OF SYMBOLS}

$M B$ Methylene blue

$M_{M B} \quad$ Amount of MB dye absorbed $[\mathrm{g} / \mathrm{kg}]$

$m_{s}$ Amount of methylene blue solution [g]

$m_{M B, 1 m l}$ Amount of methylene blue in $1 \mathrm{~g}$ of methylene blue solution $[\mathrm{g} / \mathrm{g}]$

$M_{E S}$ Amount of tested material [g]

$L_{1,2} \quad$ Limits of the confidence interval $[\mathrm{g} / \mathrm{kg}]$

$\bar{x} \quad$ Arithmetic mean $[\mathrm{g} / \mathrm{kg}]$

$\sigma \quad$ Standard deviation $[\mathrm{g} / \mathrm{kg}]$

$t_{k} \quad$ Student's T critical values

$n$ Number of measurement

\section{ACKNOWLEDGEMENTS}

The financial support of this experiment by the Czech Science Foundation (GAČR project NO. 18-10884S) and Faculty of Civil Engineering, Czech Technical University in Prague (SGS project No. SGS19/148/OHK1/3T/11) is gratefully acknowledged.

\section{REFERENCES}

[1] P. Jaquin, C. Augarde. Earth building : History, science and conservation. Report, Bracknell : IHS BRE Press, 2012.

[2] Agenda 21 - United Nations Environment Programme (UNEP). http://www.unep.org.

[3] ČSN. ČSN 1168-1939 - PODMÍNKY PRO ZEDNICKÉ A PŘIDRUŽENÉ PRÁCE POZEMNÍCH STAVEB, 1951.

[4] G. Minke. Building With Earth. Ökobuch Verlag, Staufen, 2006.

[5] I. Žabičková. Hliněné stavby. Era 21, Brno, 2002.

[6] P. Walker. Rammed Earth: Design and Construction Guidelines. IHS BRE Press, Watford, 2010.

[7] Z. Weiss. Jílové minerály : jejich nanostruktura a využití. Karolinum,, vyd. 1. edn., 2005.

[8] Evropský výbor pro normalizaci. ČSN EN 933-9, Tests for geometrical properties of aggregates - Part 9: Assessment of fines - Methylene blue test 2013. 